\title{
ZNF496 Gene
}

National Cancer Institute

\section{Source}

National Cancer Institute. ZNF496 Gene. NCI Thesaurus. Code C89027.

This gene is involved in both protein-protein interactions and the regulation of transcription. 